\title{
Expression of Na,K-ATPase- $\beta_{1}$ subunit increases uptake and sensitizes carcinoma cells to oxaliplatin
}

\author{
Ramakumar Tummala $\cdot$ Daniel Wolle $\cdot$ \\ Sonali P. Barwe $\cdot$ Valerie B. Sampson • \\ Ayyappan K. Rajasekaran · Lakshmi Pendyala
}

Received: 31 October 2008 / Accepted: 6 March 2009 / Published online: 26 March 2009

(c) The Author(s) 2009. This article is published with open access at Springerlink.com

\begin{abstract}
Purpose The ovarian carcinoma subline A2780/C10B (C10B) is an oxaliplatin resistant clone derived from the human ovarian carcinoma cell line A2780. The C10B cells are characterized by mesenchymal phenotype, decreased platinum uptake and increased glutathione levels (Hector et al. in Cancer Lett 245:195-204, 2007; Varma et al. in Oncol Rep 14:925-932, 2005). Na,K-ATPase- $\beta$ subunit $\left(\mathrm{Na}, \mathrm{K}-\beta_{1}\right)$ functions as a cell-cell adhesion molecule in epithelial cells and is reduced in a variety of carcinoma cells that show mesenchymal phenotype. The purpose of this study is to evaluate the relationship between $\mathrm{Na}, \mathrm{K}-\beta$ expression and sensitivity to oxaliplatin.

Methods Cell lines used include A2780, C10B, C10B transfected with $\mathrm{Na}, \mathrm{K}-\beta_{1}(\mathrm{C} 10 \mathrm{~B}-\mathrm{Na}, \mathrm{K}-\beta)$ and a canine kidney carcinoma cell line MSV-MDCK also transfected with Na,K- $\beta_{1}$ (MSV-MDCK- $\beta$ subunit). Cytotoxicity studies were performed by sulforhodamine-blue assay. The $\mathrm{Na}, \mathrm{K}$ $\alpha_{1}$ and $\mathrm{Na}, \mathrm{K}-\beta_{1}$ subunit localization and expression were by immunofluorescence microscopy and Western blot analysis. Platinum accumulation measurements were by atomic absorption spectrophotometry.

Results C10B cells express highly reduced levels of $\mathrm{Na}, \mathrm{K}-\beta_{1}$ subunit. Exogenous expression of $\mathrm{Na}, \mathrm{K}-\beta_{1}$ increased platinum accumulation and sensitized $\mathrm{C} 10 \mathrm{~B}$ cells to
\end{abstract}

R. Tummala $\cdot$ L. Pendyala $(\bowtie)$

Department of Medicine, Roswell Park Cancer Institute,

Elm and Carlton Streets, Buffalo, NY 14263, USA

e-mail: Lakshmi.Pendyala@ roswellpark.org

D. Wolle · S. P. Barwe · V. B. Sampson · A. K. Rajasekaran

Nemours Center for Childhood Cancer Research,

Alfred I. duPont Hospital for Children,

Wilmington, DE 19803, USA oxaliplatin. The pharmacological inhibitor of Na,K-ATPase ouabain did not alter the oxaliplatin accumulation indicating that $\mathrm{Na}, \mathrm{K}-\beta_{1}$ sensitizes cells in a Na,K-ATPase enzyme activity independent manner. These findings were also confirmed in MSV-MDCK- $\beta$ subunit cells.

Conclusions This study for the first time reveals that reduced expression of the $\mathrm{Na}, \mathrm{K}-\beta_{1}$ protein is associated with oxaliplatin resistance in cancer cells and demonstrates a novel role for this protein in sensitizing the cells to oxaliplatin. This study suggests a potentially important role for $\mathrm{Na}, \mathrm{K}-\beta_{1}$ in both prognosis and therapy of oxaliplatin resistant malignancies.

\section{Introduction}

Platinum drugs are central to many chemotherapy regimens in cancer treatment. Oxaliplatin is active in many cisplatin responsive cancers including ovarian [24], and approved for colon cancer, a cisplatin non-responsive cancer, because of its unique activity when administered in combination with 5-fluorouracil [35]. Like other forms of chemotherapy while responsive initially, platinum drug treatment can eventually result in tumor resistance. Resistance to platinum drugs, has been extensively studied especially for cisplatin and is multifactorial in nature [2,12]. Mechanisms of platinum drug resistance include drug accumulation deficiencies, intracellular detoxification, increased repair of DNA-Platinum adducts, increased tolerance to the drug and alterations in downstream signaling affecting cell death pathways [2, 12, 25]. A variety of drug resistant carcinoma cell models including of human ovarian, colon, bladder and lung have been used in these studies. Studies from our laboratory using A2780 human ovarian carcinoma cells indicated that the mechanisms of oxaliplatin resistance are 
similar to those for cisplatin, and primarily include decreased drug accumulation and increased detoxification by conjugation with glutathione $[15,16]$. These studies suggested that reduced DNA-Platinum adduct formation was a consequence of the reduced drug accumulation [15, 16]. Additionally, recent studies from our laboratory and those of others using A2780 ovarian carcinoma cells suggest that the extracellular matrix (ECM) may play a role in the resistance to oxaliplatin and cisplatin [16, 30, 34].

While mechanisms of drug resistance are extensively studied, factors that sensitize cancer cells to cytotoxic drugs are less developed and poorly understood. Epithelial to mesenchymal transition (EMT) is one of the mechanisms involved in carcinoma cell progression to metastatic and drug resistant cancer [32]. During this transition, epithelial cells lose morphology and expression of epithelial markers such as cytokeratins, and show fibroblastic phenotype characterized by increased expression of mesenchymal markers such as vimentin and fibronectin [13]. In colorectal carcinoma cell lines KM12L4 and HT-29, induction of EMT was reported to be associated with oxaliplatin resistance [36]. The A2780/C10B (C10B) is a clonal subline, selected for resistance to oxaliplatin from the parental A2780 human ovarian carcinoma cells [16]. As reported previously [16], the $\mathrm{C} 10 \mathrm{~B}$ clone was isolated using limit-dilution procedure from A2780/C10, an oxaliplatin resistant cell line derived from A2780 [9] by plating of single cell suspension and isolating a colony of $>50$ cells that was expanded. The $\mathrm{C} 10 \mathrm{~B}$ cells are spindle shaped and fibroblast-like in morphology as described in EMT with a lack of epithelial membrane antigen (EMA), whereas the parental cells exhibit epithelial phenotype with the presence of EMA [16]. Consistent with the phenotype, C10B cells have elevated levels of vimentin, and reduced levels of cytokeratins [16]. Affymetrix gene expression analysis demonstrated that the $\mathrm{C} 10 \mathrm{~B}$ cells have high expression of collagen 6 , matrix metalloproteinases and TGF- $\beta_{2}$ [34]. While it is reported that chemoresistance to paclitaxel induces EMT in ovarian carcinoma cells [21], this phenomenon is not well documented in this tumor type for oxaliplatin resistance.

The Na,K-ATPase, also known as the sodium pump is a plasma membrane bound, oligomeric enzyme localized to the basolateral plasma membrane in most epithelial cells. It is composed of two essential, non-covalently bound subunits, $\alpha_{1}\left(\mathrm{Na}, \mathrm{K}-\alpha_{1}\right)$ and $\beta_{1}\left(\mathrm{Na}, \mathrm{K}-\beta_{1}\right) . \mathrm{Na}, \mathrm{K}-\alpha_{1}$ is the catalytic subunit, whereas $\mathrm{Na}, \mathrm{K}-\beta_{1}$ is involved in the translation, stability and transport of $\mathrm{Na}, \mathrm{K}-\alpha_{1}$ on the plasma membrane [27]. Na,K-ATPase transports two $\mathrm{K}^{+}$in and three $\mathrm{Na}^{+}$out at the expense of one molecule of ATP. It not only maintains intracellular ion homeostasis but is also critical for the maintenance of polarized phenotype of epithelial cells [26]. Ouabain is a well studied pharmacological inhibitor of $\mathrm{Na}, \mathrm{K}$-ATPase which specifically binds to
$\mathrm{Na}, \mathrm{K}-\alpha$ with an $\mathrm{IC}_{50}$ of $10 \mathrm{nM}$ in most human cell types [19]. Well differentiated epithelial cells express high levels of $\mathrm{Na}, \mathrm{K}-\beta_{1}$, whereas poorly differentiated carcinoma cells with mesenchymal phenotype express reduced levels of this protein $[11,28]$. Na, $\mathrm{K}-\beta_{1}$ levels were drastically reduced in highly motile and invasive carcinoma cell lines [11] and correlate with their invasiveness and metastatic potential $[18,28]$. Restoration of $\mathrm{Na}, \mathrm{K}-\beta_{1}$ in Moloney Sarcoma virus transformed Madin-Darby canine kidney cells (MSVMDCK) suppressed motility, invasion [6, 28] and tumorigenicity [18]. These studies strongly indicated a functional link between reduced $\mathrm{Na}, \mathrm{K}-\beta_{1}$ expression and cancer progression.

In this study, we tested the hypothesis that reduced expression of $\mathrm{Na}, \mathrm{K}-\beta_{1}$ in $\mathrm{C} 10 \mathrm{~B}$ is associated with oxaliplatin resistance by evaluating the relationship between oxaliplatin sensitivity, $\mathrm{Na}, \mathrm{K}-\beta_{1}$ expression, and platinum accumulation in $\mathrm{C} 10 \mathrm{~B}$ cells in comparison with the parental $\mathrm{A} 2780$ and $\mathrm{C} 10 \mathrm{~B}$ cells transfected with $\mathrm{Na}, \mathrm{K}-\beta_{1}$ subunit $(\mathrm{C} 10 \mathrm{~B}-\mathrm{Na}, \mathrm{K}-\beta)$. Results presented here reveal that the resistant $\mathrm{C} 10 \mathrm{~B}$ cells have reduced expression of $\mathrm{Na}, \mathrm{K}-\beta_{1}$. Exogenous expression of $\mathrm{Na}, \mathrm{K}-\beta_{1}$ results in increased oxaliplatin uptake and cellular sensitivity to the drug, independent of $\mathrm{Na}, \mathrm{K}-\mathrm{ATPase}$ enzyme activity.

\section{Materials and methods}

\section{Drugs}

Oxaliplatin was a gift from Dr. Paul Juniewicz of SanofiSynthelabo (Malvern, PA).

\section{Cell lines}

The ovarian carcinoma cell line A2780 was a gift from Dr. Ozols (Fox Chase Cancer Center, Philadelphia, PA). The oxaliplatin resistant C10B subline was derived as a single cell clone from a previously described A2780/C10 cell line [9]. A pooled clone of C10B cells stably expressing $\mathrm{Na}, \mathrm{K}-\beta_{1}(\mathrm{C} 10 \mathrm{~B}-\mathrm{Na}, \mathrm{K}-\beta)$ was generated by transfecting the $\mathrm{C} 10 \mathrm{~B}$ cells with human $\mathrm{Na}, \mathrm{K}-\beta_{1}$ cDNA in a mammalian expression vector with neomycin resistance (pcDNA3.1 from Invitrogen, Carlsbad, CA). C10B cells transfected with the empty vector (C10B-Vector) were used as a control. The ovarian carcinoma cell lines and the C10B$\mathrm{Na}, \mathrm{K}-\beta$ cells were maintained in RPMI 1640 supplemented with $10 \%$ heat inactivated fetal bovine serum (FBS) and $1 \%$ L-glutamine (Invitrogen, Grand Island, NY). Other cell lines used in the study included MSV-MDCK cells stably transfected with pcDNA3.1 vector (MSV-MDCK-vector) or Na,K- $\beta_{1}$ (MSV-MDCK- $\beta$ subunit). Generation of these cell lines has been described previously [28]. These cells 
were grown in DMEM with $10 \% \mathrm{FBS}, 1 \%$ penicillin and streptomycin and $200 \mu \mathrm{g} / \mathrm{ml}$ neomycin.

\section{Cytotoxicity assays}

Cytotoxicity analysis was carried out using sulforhodamineblue (SRB) assay as described previously [16]. Cells were continuously exposed to oxaliplatin for $72 \mathrm{~h}$, fixed and subjected to the SRB assay. The optical density (OD) was read at $570 \mathrm{~nm}$ (EL309 Automated Microplate Reader, Bio-Tek Instruments, Winooski, VT) and percent survival was determined as $\left[\mathrm{OD}_{570}\right.$ (treated cells)/OD $\mathrm{OD}_{570}$ (untreated cells) $] \times 100$.

\section{Platinum accumulation}

Cells were exposed to oxaliplatin $(100 \mu \mathrm{M})$ for $2 \mathrm{~h}$, washed thoroughly with PBS and total intracellular platinum was measured as previously described [15]. For this drug exposed cells were trypsinized and centrifuged into a pellet and lysed in $0.5 \mathrm{ml}$ of $0.1 \%$ Triton $\mathrm{X}-100$ and $0.2 \%$ nitric acid overnight and sonicated for $1 \mathrm{~min}$. Platinum in the cell lysate was measured by graphite furnace atomic absorption spectrophotometry with Zeeman background correction (PE 4100ZL, Norwalk, CT). Protein was measured using the Bradford assay. In experiments aimed at Na,K-ATPase inhibition, cells were pretreated with ouabain $(50 \mu \mathrm{M})$ for 15 min prior to oxaliplatin exposure with a continued incubation with ouabain $(50 \mu \mathrm{M})$ also during the exposure to oxaliplatin.

\section{Immunofluorescence}

Cells grown on cover slips were fixed with chilled methanol, incubated with antibodies against $\mathrm{Na}, \mathrm{K}-\beta_{1}$ or $\mathrm{Na}, \mathrm{K}-\alpha_{1}$ and stained with Alexa Fluor 488 conjugated goat anti-mouse antibody (Invitrogen). Samples were excited with an argon laser, and the light emitted around $519 \mathrm{~nm}$ was recorded. Images were obtained using a confocal microscope Leica TCS SP5 (Leica Microsystems Inc., Bannockburn, IL).

Reverse transcription and quantitative real-time PCR

Total RNA was isolated from A2780, C10B and C10B$\mathrm{Na}, \mathrm{K}-\beta$ cells using the RNA Aqueous kit (Ambion, Austin, TX). RNA concentration was measured using the Nanodrop Spectrophotometer (Thermo Fisher Scientific, Waltham, MA). First strand cDNA was generated from total RNA using the High Capacity cDNA kit (Applied Biosystems, Foster City, CA). One microgram of RNA was reverse transcribed to cDNA according to the manufacturer's protocol. Quantitative RT-PCR analysis of ATP1B1 was performed using the ATP1B1 gene specific TaqMan MGB assay and
TaqMan universal master mix on an ABI 7900HT System from Applied Biosystems. The 'comparative threshold' method was used to calculate relative gene expression. Values were normalized against $18 \mathrm{~S}$ rRNA.

Western blot analysis

Immunoblot analysis was performed as described previously [28]. Cells were lysed in a buffer containing $20 \mathrm{mM}$ Tris- $\mathrm{HCl}, \mathrm{pH}$ 7.4, $100 \mathrm{mM} \mathrm{NaCl}, 1 \%$ Triton X-100, $1 \mathrm{mM}$ EDTA, $1 \mathrm{mM}$ EGTA, $1 \mathrm{mM}$ sodium glycerolphosphate, $1 \mathrm{mM}$ sodium orthovanadate, $1 \mathrm{mM}$ PMSF, and $5 \mu \mathrm{g} / \mathrm{ml}$ each of antipain, leupeptin and pepstatin. The lysates were sonicated, and clarified by centrifugation at 13,000 rpm for $10 \mathrm{~min}$ at $4^{\circ} \mathrm{C}$. Total protein was estimated from the supernatants using the Bio-Rad DC reagent (Bio-Rad, Hercules, CA) as per manufacturer's instructions. Total protein $(50 \mu \mathrm{g})$ was resolved on SDS-PAGE and transferred to nitrocellulose membrane (Schleicher \& Schuell, Keene, $\mathrm{NH})$. Immunoblotting was performed using a primary antibody, and HRP-conjugated secondary antibody diluted in tris-buffered saline containing 5\% non-fat dried milk and $0.1 \%$ Tween 20 . The proteins were detected by using the enhanced chemiluminescence lighting system according to the manufacturer's recommendations (PerkinElmer Life and Analytical Sciences, Boston, MA). The bands from two independent experiments were quantified using GeneTools software from PerkinElmer, Waltham, MA. Na,K- $\beta_{1}$ and $\mathrm{Na}, \mathrm{K}-\alpha_{1}$ antibodies were a gift from Dr. William James Ball Jr., University of Cincinnati, Cincinnati. Anti-fibronectin and E-cadherin antibodies were from BD Biosciences, San Jose, CA. $\beta$-Actin (Sigma, St. Louis, MO) was used as a loading control.

Statistical analysis

Significance of differences in cytotoxicity and platinum accumulation was evaluated using Student's $t$ test (Systat Software Inc., Richmond, CA).

\section{Results}

Expression of Na,K- $\beta_{1}$ in A2780, C10B and C10B-Na,K- $\beta$ cells

A2780 cells express high levels of $\mathrm{Na}, \mathrm{K}-\beta_{1}$ compared to C10B (Fig. 1a). Exogenous expression of $\mathrm{Na}, \mathrm{K}-\beta_{1}$ in $\mathrm{C} 10 \mathrm{~B}$ cells increased $\mathrm{Na}, \mathrm{K}-\beta_{1}$ levels comparable to its expression in A2780 (Fig. 1a). There was a 50\% reduction in Na,K- $\beta_{1}$ transcript levels in $\mathrm{C} 10 \mathrm{~B}$ cells compared to A2780 cells (Fig. 1b) consistent with the reduction at the protein level. There was no significant change in the $\mathrm{Na}, \mathrm{K}-\alpha_{1}$ levels in all 
Fig. 1 a Immunoblot analysis of Na,K-ATPase subunits, fibronectin, E-cadherin and actin in parental A2780, C10B and C10B-Na,K- $\beta$ cells. Densitometric quantitations are included under each panel. b Relative mRNA expression using quantitative real-time PCR. c Morphological characterization and localization of Na,K-ATPase subunits by phase contrast and epifluorescence microscopy. Bar $20 \mu \mathrm{m}$
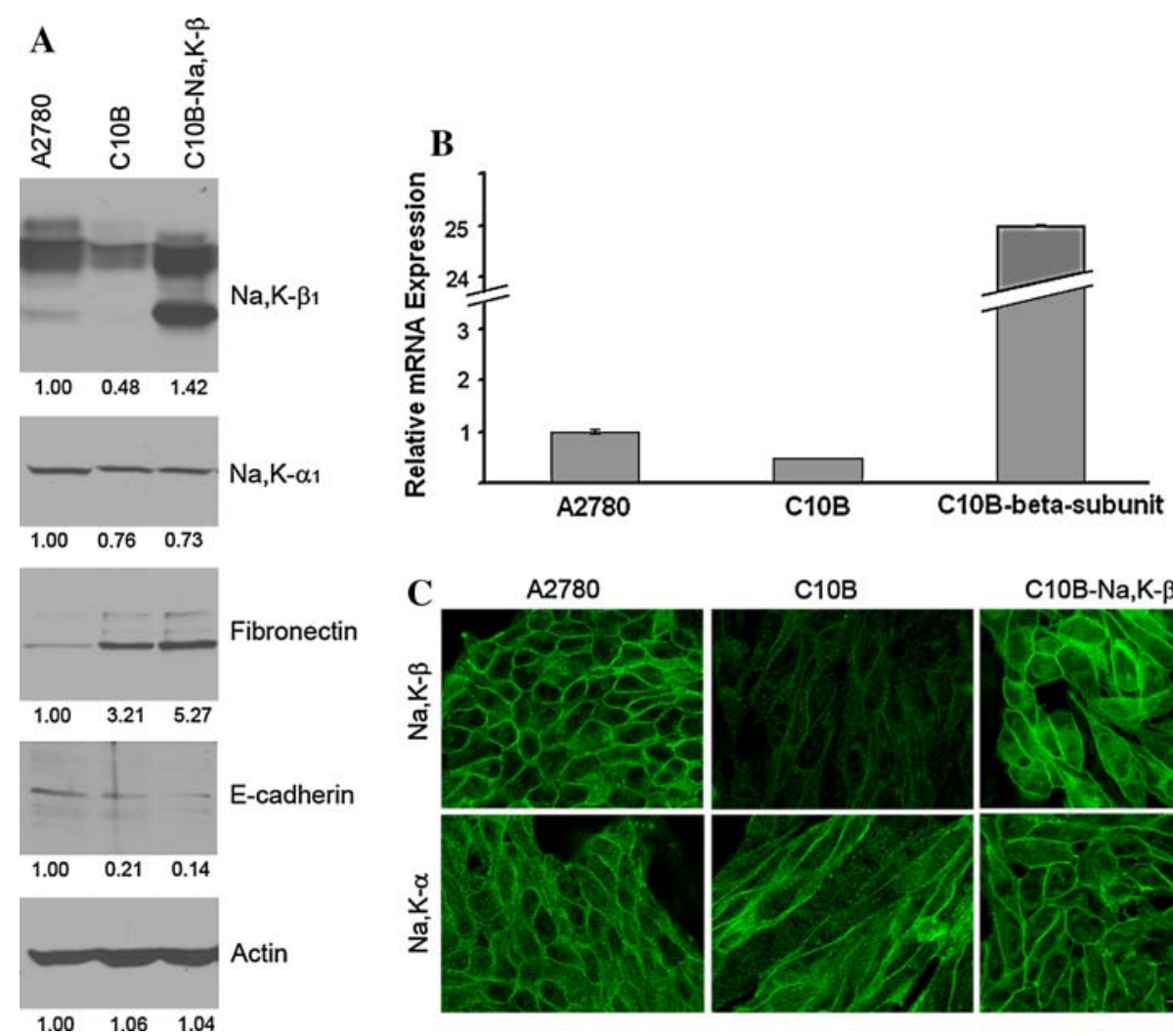

these cell lines (Fig. 1a). However, they were similar between $\mathrm{C} 10 \mathrm{~B}$ and $\mathrm{C} 10 \mathrm{~B}-\mathrm{Na}, \mathrm{K}-\beta$ cells (Fig. 1a). As expected both $\mathrm{Na}, \mathrm{K}-\alpha_{1}$ and $\mathrm{Na}, \mathrm{K}-\beta_{1}$ were localized to the plasma membrane in A2780 and C10B-NaK- $\beta_{1}$ cells (Fig. 1c). Consistent with the immunoblot analysis, C10B cells revealed highly reduced levels of $\mathrm{Na}, \mathrm{K}-\beta_{1}$ (Fig. 1c). Morphologically, C10B cells showed a fibroblastic phenotype, whereas, the A2780 were adherent to each other and showed epithelial like morphology (Fig. 1c). Interestingly, following $\mathrm{Na}, \mathrm{K}-\beta_{1}$ expression $\mathrm{C} 10 \mathrm{~B}$ cells grew adherent to each other and appeared morphologically similar to A2780 cells (Fig. 1c). Expression of mesenchymal marker fibronectin is one of the hallmarks of EMT [17]. Consistent with the fibroblastic morphology, the $\mathrm{C} 10 \mathrm{~B}$ cells expressed high levels of fibronectin which was present at a lower level in parental A2780 cells (Fig. 1a). On the other hand, the expression of the epithelial marker, E-cadherin was greatly reduced in C10B cells (Fig. 1a). Although Na,K- $\beta_{1}$ expression induced morphological changes there was no change in the levels of fibronectin and E-cadherin compared to C10B cells (Fig. 1b). This result indicates that exogenous expression of $\mathrm{Na}, \mathrm{K}-\beta_{1}$ in these cells did not reverse the EMT.

Increased sensitivity to oxaliplatin in $\mathrm{Na}, \mathrm{K}-\beta_{1}$ transfected C10B cells

The sensitivity profiles of the parental A2780 cells to oxaliplatin along with the resistant $\mathrm{C} 10 \mathrm{~B}$, the $\mathrm{C} 10 \mathrm{~B}-\mathrm{Na}, \mathrm{K}-\beta$
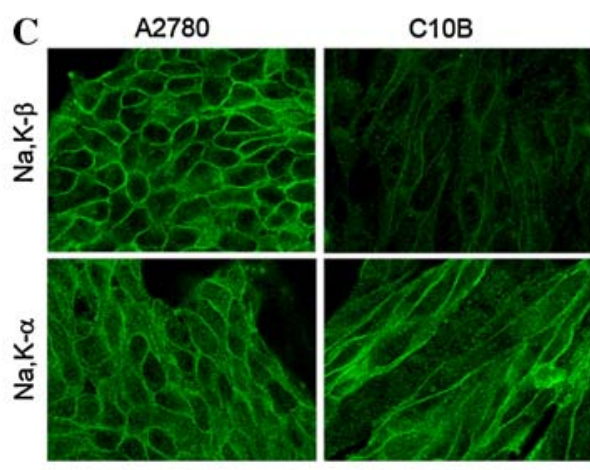

C10B-Na,K- $\beta$

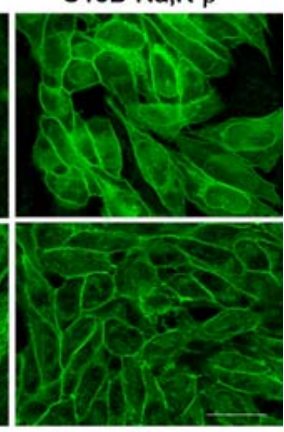

and the vector control are shown in Fig. 2a. The C10B$\mathrm{Na}, \mathrm{K}-\beta$ cells $\left(\mathrm{IC}_{50}=1 \mu \mathrm{M}\right)$ were significantly sensitized to oxaliplatin as compared to the resistant $\mathrm{C} 10 \mathrm{~B}$ cells $\left(\mathrm{IC}_{50}=3 \mu \mathrm{M}\right) \quad$ or the vector control $\left(\mathrm{IC}_{50}=2 \mu \mathrm{M}\right)$ although their sensitivity was not as high as the parental A2780 cells $\left(\mathrm{IC}_{50}=0.2 \mu \mathrm{M}\right)$. The enhanced sensitivity of C10B-Na,K- $\beta$ cells to oxaliplatin was statistically significant compared to $\mathrm{C} 10 \mathrm{~B}$ cells or the vector transfected cells $(P<0.01)$.

Increased drug accumulation in $\mathrm{Na}, \mathrm{K}-\beta_{1}$ transfected $\mathrm{C} 10 \mathrm{~B}$ cells

We previously reported that $\mathrm{C} 10 \mathrm{~B}$ cells are deficient in drug accumulation compared to the parental A2780 cells [16]. Since the C10B-Na,K- $\beta$ cells exhibit increased sensitivity to oxaliplatin compared to the resistant, $\mathrm{C} 10 \mathrm{~B}$ cells, we investigated if there was an altered drug accumulation in these cells. C10B-Na,K- $\beta$ cells showed about sixfold higher platinum accumulation as compared to the $\mathrm{C} 10 \mathrm{~B}$ or the vector cells (Fig. 2b). This increase was highly statistically significant $(P<0.001)$. The amount of platinum accumulated by $\mathrm{C} 10 \mathrm{~B}-\mathrm{Na}, \mathrm{K}-\beta$ cells was even higher than the parental cells under identical conditions of treatment $(P=0.005)$. These results suggest that there is a positive correlation between $\mathrm{Na}, \mathrm{K}-\beta_{1}$ expression and increased platinum accumulation. 

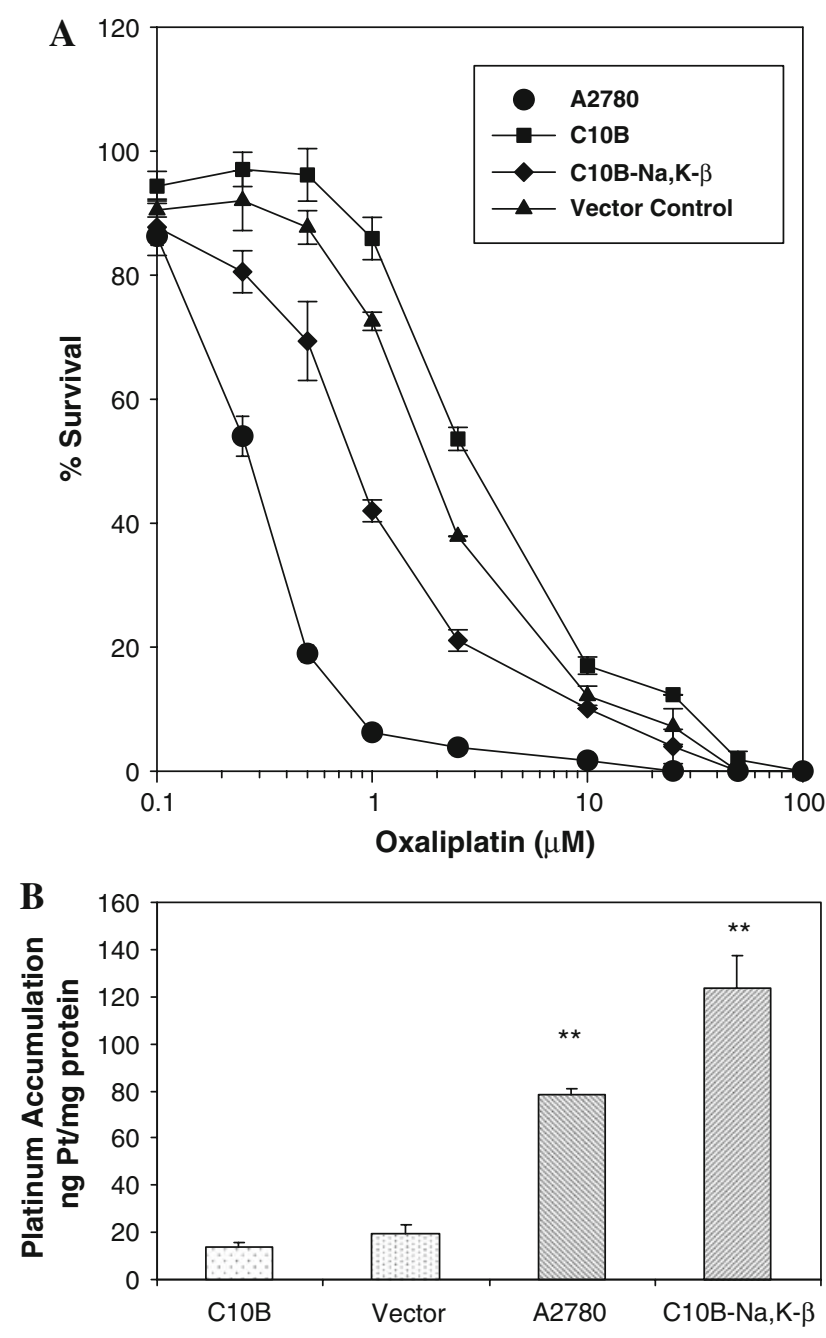

Fig. 2 a Growth inhibition dose response curves for A2780, C10B, C10B-Na,K- $\beta$ and vector control following a $72 \mathrm{~h}$ exposure to oxaliplatin. Data represents percent growth as determined by $\left(\mathrm{OD}_{570}\right.$ of treated cells $/ \mathrm{OD}_{570}$ of untreated cells) $\times 100$. Data represent mean $\pm \mathrm{SD}$, $n=3$. $\mathrm{IC}_{50}$ 's A2780: $0.2 \mu \mathrm{M}$; C10B: $3 \mu \mathrm{M}$; C10B-Na,K- $\beta: 1 \mu \mathrm{M}$ and Vector: $2 \mu \mathrm{M}$. b Accumulation of Pt in C10B, Vector control, A2780 and $\mathrm{C} 10 \mathrm{~B}-\mathrm{Na}, \mathrm{K}-\beta$ following oxaliplatin treatment. Platinum accumulation following exposure to $100 \mu \mathrm{M}$ oxaliplatin for $2 \mathrm{~h}$. Data represent mean $\pm \mathrm{SD}, n=3$. The $* *$ represent statistically highly significant difference compared to $\mathrm{C} 10 \mathrm{~B}$ or vector $(P<0.001)$. The difference between $\mathrm{A} 2780$ and $\mathrm{C} 10 \mathrm{~B}-\mathrm{Na}, \mathrm{K}-\beta$ is also statistically significant $(P=0.005)$

Confirmation of the sensitization and drug accumulation phenomenon in MSV-MDCK- $\beta$ subunit cells

Sensitization to oxaliplatin by exogenous expression of $\mathrm{Na}, \mathrm{K}-\beta_{1}$ was investigated in another cell line to test whether this phenomenon is specific to ovarian cells or occurs in other cell type as well. MSV-MDCK cells expresses low levels of $\mathrm{Na}, \mathrm{K}-\beta_{1}$ and are highly invasive and metastatic (Fig. 3a). Exogenous expression of Na,K- $\beta_{1}$ in MSV-MDCK cells (MSV-MDCK- $\beta$ subunit) reduced their motility, invasiveness and tumorigenic potential [28]. Cytotoxicity and platinum accumulation studies indicated that MSV-MDCK- $\beta$ subunit cells were more sensitive to oxaliplatin as compared to the parental cells carrying the vector and do not express this protein (Fig. 3b). Further studies confirmed a statistically significant $(P<0.05)$ increase in the accumulation of platinum in MSV-MDCK $\beta$ cells (Fig. 3c) indicating that Na,K- $\beta_{1}$ expression facilitates oxaliplatin uptake and increases sensitivity to this drug.

Oxaliplatin accumulation and resulting sensitization to oxaliplatin is independent of the pump function of $\mathrm{Na}, \mathrm{K}$-ATPase

In order to determine whether the Na,K-ATPase enzyme activity determines the changes in altered drug accumulation, both C10B-Na,K- $\beta$ cells and the MSV-MDCK- $\beta$ subunit cells were treated with ouabain, a pharmacological inhibitor of $\mathrm{Na}, \mathrm{K}$-ATPase. Ouabain at $50 \mu \mathrm{M}$ concentration that we used in our experiments is known to completely inhibit Na,K-ATPase activity in human and canine cells [19]. The results show that there is no significant difference in platinum accumulation in ouabain treated versus untreated cells (Fig. 4a, b), suggesting that the pump function of Na,K-ATPase might not be involved in the observed increases in drug uptake and sensitization to oxaliplatin in these cells.

\section{Discussion}

The exogenous expression of $\mathrm{Na}, \mathrm{K}-\beta_{1}$ in the oxaliplatin resistant $\mathrm{C} 10 \mathrm{~B}$ cells increased the uptake and cell sensitivity to the drug. Increased uptake and sensitization of cells to the drug were independently confirmed in kidney carcinoma cells expressing $\mathrm{Na}, \mathrm{K}-\beta_{1}$. Our data also suggests that $\mathrm{Na}, \mathrm{K}-\beta_{1}$ expression increases sensitivity to oxaliplatin independent of Na,K-ATPase pump function. Thus, these results for the first time reveal that reduced expression of $\mathrm{Na}, \mathrm{K}-\beta_{1}$ protein is associated with oxaliplatin resistance and that increasing its levels enhances oxaliplatin sensitivity of carcinoma cells.

Reduced drug accumulation is one of the commonly described mechanisms for platinum drug resistance in many studies with a strong correlation between platinum accumulation and relative resistance as demonstrated in human hepatoma BEL7404 cells with increasing acquired resistance to cisplatin [20], and primary bladder cancer cell lines with intrinsic resistance to cisplatin [23]. While there is a consensus that drug accumulation is a major determinant of platinum drug sensitivity, the mechanisms involved in uptake are still not well understood. In addition, much of the work to date is on the prototype drug cisplatin and rela- 

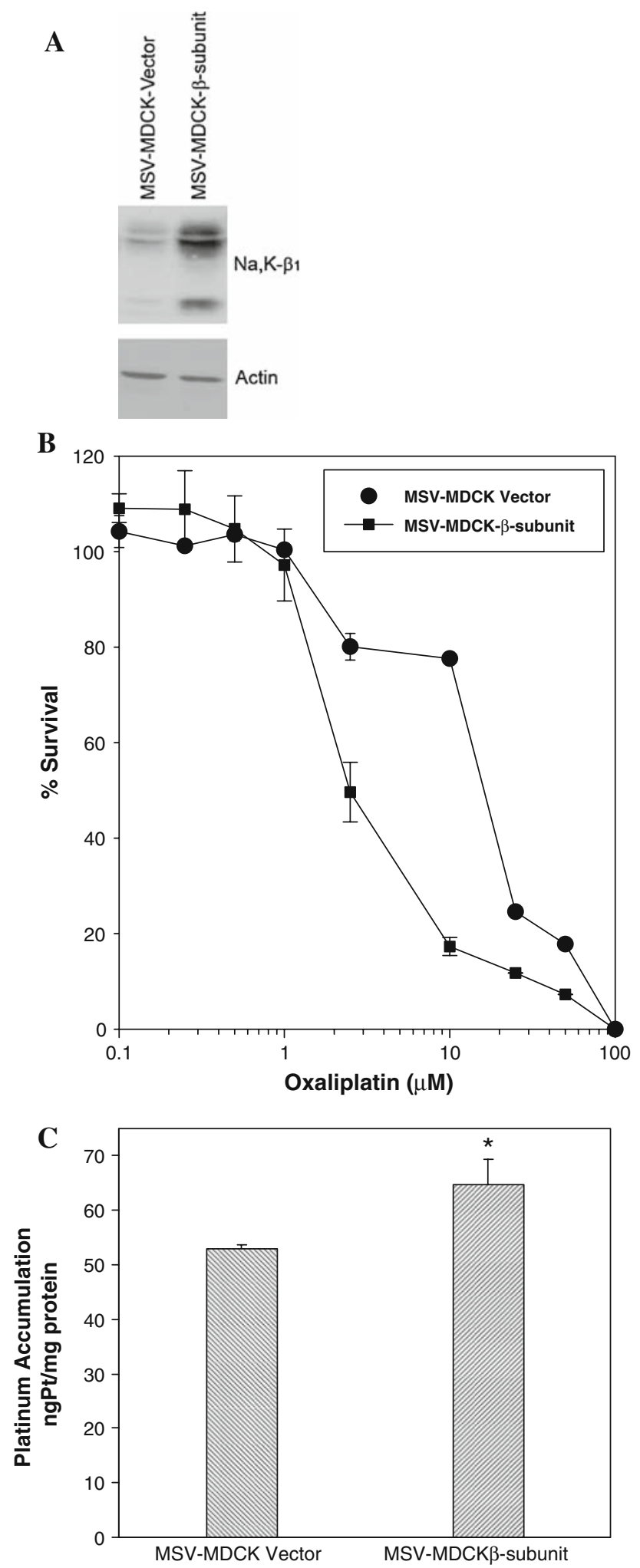

tively fewer reports exist on the uptake of other platinum analogs including oxaliplatin. In a recent review, Hall et al. [14] discuss the current evidence for how cisplatin enters the cells, its potential extrusion out of cells and cellular changes in resistance including information that is available
Fig. 3 a Immunoblot showing levels of $\mathrm{Na}, \mathrm{K}-\beta_{1}$ in MSV-MDCK cells. b Growth inhibition dose response curves for MSV-MDCK vector and MSV-MDCK- $\beta$-subunit following $72 \mathrm{~h}$ exposure to oxaliplatin. Data represents percent growth as determined by $\left(\mathrm{OD}_{570}\right.$ of treated cells $/ \mathrm{OD}_{570}$ of untreated cells) $\times 100$. Data expressed as mean $\pm \mathrm{SE}$ where $n=3$. IC s0 $_{50}$ ' Vector: $18 \mu \mathrm{M}$, MSV-MDCK- $\beta$ : $2.5 \mu \mathrm{M}$. c Platinum accumulation following exposure to $100 \mu \mathrm{M}$ oxaliplatin for $2 \mathrm{~h}$ in MSV-MDCK vector and MSV-MDCK- $\beta$ cells. Data represent mean \pm $\mathrm{SD}, n=3$. The * represent statistically significant difference $(P=0.016)$
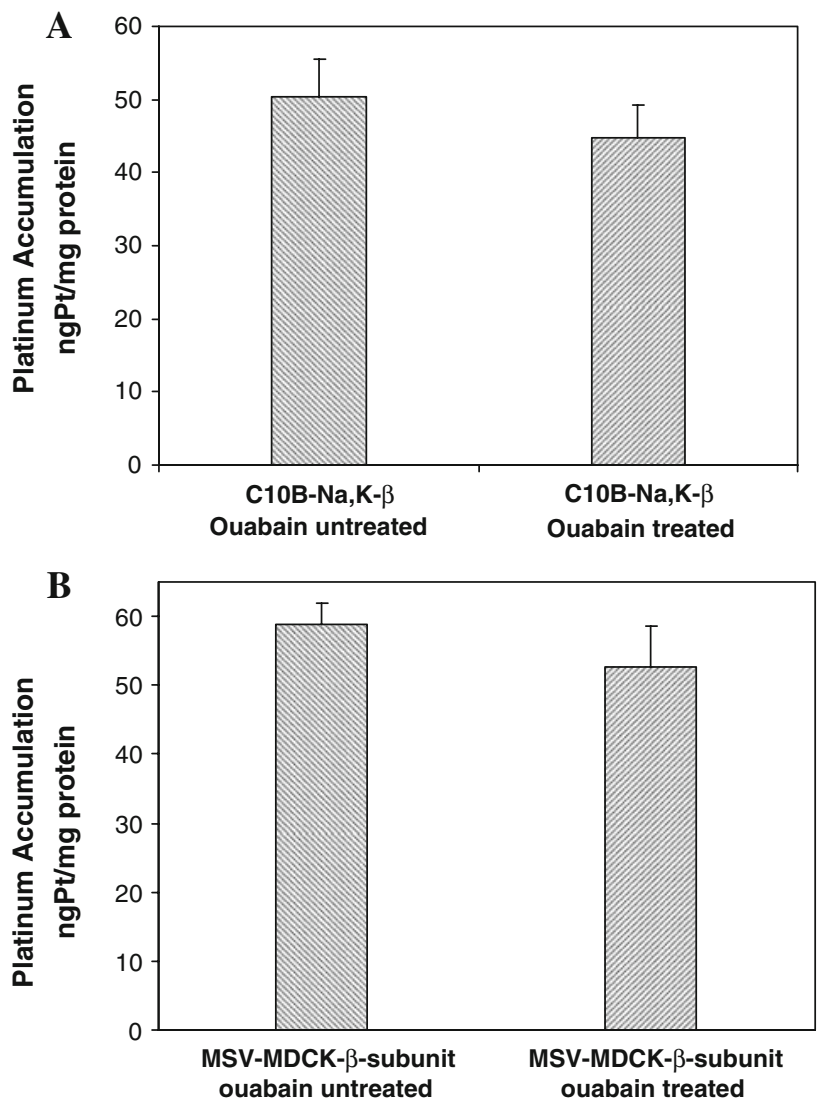

Fig. 4 a Accumulation of platinum in C10B-Na,K- $\beta$ cells exposed to oxaliplatin $(100 \mu \mathrm{M}$ for $2 \mathrm{~h})$ with and without ouabain $(50 \mu \mathrm{M})$ treatment. Data represent mean $\pm \mathrm{SD}, n=3$. b Accumulation of platinum in MSV-MDCK- $\beta$ cells exposed to oxaliplatin ( $100 \mu \mathrm{M}$ for $2 \mathrm{~h}$ ) with and without ouabain $(50 \mu \mathrm{M})$ treatment. Data represent mean $\pm \mathrm{SD}$, $n=3$

for the platinum analogs. Most of the evidence suggests that cisplatin uptake and possibly of other analogs involves multiple mechanisms including diffusion, CTR1 copper influx transporter mediated uptake (of cisplatin but not oxaliplatin) [29], and organic cation transporters (SLC family members OCT1 and 2) which may be involved in oxaliplatin uptake [37]. It was suggested that the potential speciation in various media of platinum analogs that imparts the charged versus neutral characteristics to these drugs could in addition dictate which mechanism of transport may play a major role [14]. In the absence of evidence for changes in 
physicochemical properties of membranes accounting for altered diffusion in resistant cells, the available evidence only points to alterations in transport proteins [14]. A potential role for copper efflux transporters ATP7A/7B and glutathione conjugate pump (GS-X family) in the efflux of cisplatin and resistance to the drug has been described $[8,22]$.

$\mathrm{Na}, \mathrm{K}-\mathrm{ATPase}$ enzyme function mediated transport has also been suggested as a potential mechanism in cisplatin uptake $[4,14]$. While the experiments with ouabain inhibition indicated a potential role for $\mathrm{Na}, \mathrm{K}$-ATPase in cisplatin uptake into 2008 human ovarian carcinoma cells and their cisplatin resistant variant A2780/DDP [4], no differences in $\mathrm{Na}, \mathrm{K}-\mathrm{ATPase}$ activity between cisplatin sensitive and resistant cells have been observed [3]. Their studies suggested for a $\mathrm{Na}^{+}$-dependent transporter for cisplatin. In separate experiments primarily aimed at disrupting the sodium gradient they concluded that it is the sodium gradient dissipation, which is also resulting from the inhibition of $\mathrm{Na}, \mathrm{K}-\mathrm{ATPase}$ activity by ouabain that is affecting the cisplatin accumulation [3]. In a panel of human small cell lung cancer (SCLC) and human non-small cell lung cancer (NSCLC) cell lines all expressing Na,K-ATPase activity, ouabain inhibition lowered cisplatin accumulation in NSCLC cell lines, but not in SCLC, suggesting that other factors distinct from the pump activity may have an impact on cisplatin uptake into cells [5]. A more recent report connects Na,K-ATPase activity and not ATP-7A and ATP-7B in cisplatin sensitivity in oral squamous cell carcinoma cells [1]. At the moment it is unclear what the exact role of $\mathrm{Na}, \mathrm{K}$-ATPase function is in cisplatin uptake, or a role if there is any for oxaliplatin uptake. In the two cell models transfected with $\mathrm{Na}, \mathrm{K}-\beta_{1}$, we did not observe any change in platinum uptake following ouabain treatment. In our experiments, by increased expression of $\mathrm{Na}, \mathrm{K}-\beta_{1}$ in ovarian carcinoma cells, restoration to sensitivity was achieved partially, but not completely indicating the multi-factorial nature of resistance such as high levels of glutathione in C10B cells that we described earlier [16].

The parental A2780 cells are adherent to each other and show epithelial phenotype. The C10B cells on the other hand were of mesenchymal phenotype indicating that during the selection of oxaliplatin resistance the A2780 cells have undergone EMT. This is further confirmed by the increased levels of fibronectin in C10B cells (present study), positivity for vimentin [16] and up-regulated expression of genes of extracellular matrix, such as matrix metalloproteinases, integrin alpha and TGF- $\beta_{2}$ [34], genes described to be either part of EMT and/or part of the extracellular matrix mediated drug resistance [10]. Interestingly, although expression of $\mathrm{Na}, \mathrm{K}-\beta_{1}$ induced an adherent phenotype as revealed by the change in the morphology of C10B-Na,K- $\beta_{1}$ cells, there was no change in the levels of fibronectin compared to C10B cells. This result suggests that the reversal of EMT, i.e., mesenchymal to epithelial transition (MET) has not taken place in these cells at least at the molecular level. This is also the case with MSVMDCK cells expressing Na,K- $\beta_{1}$. These cells have not reverted their mesenchymal phenotype but are more adherent to each other, show reduced motility $[6,28]$ and tumorigenicity [18]. We and others recently showed that $\mathrm{Na}, \mathrm{K}-\beta_{1}$ is a cell-cell adhesion molecule and increases cell-cell contact when expressed in carcinoma cells [7, 31, 33]. Although the mechanism/s by which $\mathrm{Na}, \mathrm{K}-\beta_{1}$ increases sensitivity to oxaliplatin is not known, it is tempting to speculate that the cell-cell adhesion function of $\mathrm{Na}, \mathrm{K}-\beta_{1}$ might be involved in this process. It is possible that cells that are contact naive are less sensitive to drugs compared to cells adherent to each other. Future experiments are necessary to unravel mechanisms by which $\mathrm{Na}, \mathrm{K}-\beta_{1}$ is increasing the drug uptake and sensitizing cells for oxaliplatin. However, the current findings have immense therapeutic potential. First, Na,K- $\beta_{1}$ levels could be used as a biomarker for screening patients that would respond better to platinum based chemotherapy. Secondly, it may be possible to target the cancer cells which have become drug-insensitive by increasing the levels of $\mathrm{Na}, \mathrm{K}-\beta_{1}$ in these cells using targeted gene therapy approaches. We suggest that ability to increase the expression of $\mathrm{Na}, \mathrm{K}-\beta_{1}$ should have significant therapeutic value for treating drug-insensitive malignancies.

Acknowledgments This work was supported in part by NCICA 109619 (LP) and NIHDK56216 (AR). We acknowledge the support of Comprehensive Cancer Center grant NCICA10656 for the Pharmacokinetics/Pharmacodynamics Core Facility usage.

Open Access This article is distributed under the terms of the Creative Commons Attribution Noncommercial License which permits any noncommercial use, distribution, and reproduction in any medium, provided the original author(s) and source are credited.

\section{References}

1. Ahmed Z, Deyama Y, Yoshimura Y, Suzuki K (2008) Cisplatin sensitivity of oral squamous carcinoma cells is regulated by $\mathrm{Na}(+)$, $\mathrm{K}(+)$-ATPase activity rather than copper-transporting P-type ATPases, ATP7A and ATP7B. Cancer Chemother Pharmacol 63(4):643-650

2. Andrews PA (1994) Mechanisms of acquired resistance to cisplatin. Cancer Treat Res 73:217-248

3. Andrews PA, Mann SC, Huynh HH, Albright KD (1991) Role of the $\mathrm{Na}+\mathrm{K}(+)$-adenosine triphosphatase in the accumulation of cisdiamminedichloroplatinum(II) in human ovarian carcinoma cells. Cancer Res 51:3677-3681

4. Andrews PA, Velury S, Mann SC, Howell SB (1988) cis-Diamminedichloroplatinum(II) accumulation in sensitive and resistant human ovarian carcinoma cells. Cancer Res 48:68-73

5. Bando T, Fujimura M, Kasahara K, Matsuda T (1998) Significance of $\mathrm{Na}+\mathrm{K}(+)$-ATPase on intracellular accumulation of 
cis-diamminedichloroplatinum(II) in human non-small-cell but not in small-cell lung cancer cell lines. Anticancer Res 18:10851089

6. Barwe SP, Anilkumar G, Moon SY, Zheng Y, Whitelegge JP, Rajasekaran SA, Rajasekaran AK (2005) Novel role for Na,KATPase in phosphatidylinositol 3-kinase signaling and suppression of cell motility. Mol Biol Cell 16:1082-1094

7. Barwe SP, Kim S, Rajasekaran SA, Bowie JU, Rajasekaran AK (2007) Janus model of the Na,K-ATPase beta-subunit transmembrane domain: distinct faces mediate alpha/beta assembly and beta-beta homo-oligomerization. J Mol Biol 365:706-714

8. Borst P, Kool M, Evers R (1997) Do cMOAT (MRP2), other MRP homologues and LRP play a role in MDR? Semin Cancer Biol $8: 205-213$

9. El-akawi Z, Abu-hadid M, Perez R, Glavy J, Zdanowicz J, Creaven PJ, Pendyala L (1996) Altered glutathione metabolism in oxaliplatin resistant A2780 ovarian carcinoma cells. Cancer Let 105:5-14

10. Elliott T, Sethi T (2002) Integrins and extracellular matrix. Expert Rev Anticancer Ther 2:449-459

11. Espineda CE, Chang JH, Twiss J, Rajasekaran SA, Rajasekaran AK (2004) Repression of Na,K-ATPase beta1-subunit by the transcription factor snail in carcinoma. Mol Biol Cell 15:1364-1373

12. Gosland M, Lum B, Schimmelpfennig J, Baker J, Doukas M (1996) Insights into mechanisms of cisplatin resistance and potential for its clinical reversal. Pharmacotherapy 16:16-39

13. Guarino M, Rubino B, Ballabio G (2007) The role of epithelialmesenchymal transition in cancer pathology. Pathology (Phila) 39:305-318

14. Hall MD, Okabe M, Shen DW, Liang XJ, Gottesman MM (2008) The role of cellular accumulation in determining sensitivity to platinum-based chemotherapy. Annu Rev Pharmacol Toxicol 48:495-535

15. Hector S, Bolanowska-Higdon W, Zdanowicz J, Hitt S, Pendyala L (2001) In vitro studies on the mechanisms of oxaliplatin resistance. Cancer Chemother Pharmacol 48:398-406

16. Hector S, Nava ME, Clark K, Murpy M, Pendyala L (2007) Characterization of a clonal isolate of an oxaliplatin resistant ovarian carcinoma cell line A2780/C10. Cancer Lett 245:195-204

17. Huber MA, Kraut N, Beug H (2005) Molecular requirements for epithelial-mesenchymal transition during tumor progression. Curr Opin Cell Biol 17:548-558

18. Inge LJ, Rajasekaran SA, Yoshimoto K, Mischel PS, McBride W, Landaw E, Rajasekaran AK (2008) Evidence for a potential tumor suppressor role for the Na,K-ATPase beta1-subunit. Histol Histopathol 23:459-467

19. Jewell EA, Lingrel JB (1991) Comparison of the substrate dependence properties of the rat $\mathrm{Na}, \mathrm{K}-\mathrm{ATPase}$ alpha 1 , alpha 2 , and alpha 3 isoforms expressed in HeLa cells. J Biol Chem 266:16925-16930

20. Johnson SW, Shen D, Pastan I, Gottesman MM, Hamilton TC (1996) Cross-resistance, cisplatin accumulation, and platinum-DNA adduct formation and removal in cisplatin-sensitive and -resistant human hepatoma cell lines. Exp Cell Res 226:133-139

21. Kajiyama H, Shibata K, Terauchi M, Yamashita M, Ino K, Nawa A, Kikkawa F (2007) Chemoresistance to paclitaxel induces epithelial-mesenchymal transition and enhances metastatic potential for epithelial ovarian carcinoma cells. Int J Oncol 31:277-283

22. Katano K, Kondo A, Safaei R, Holzer A, Samimi G, Mishima M, Kuo YM, Rochdi M, Howell SB (2002) Acquisition of resistance to cisplatin is accompanied by changes in the cellular pharmacology of copper. Cancer Res 62:6559-6565

23. Koga H, Kotoh S, Nakashima M, Yokomizo A, Tanaka M, Naito S (2000) Accumulation of intracellular platinum is correlated with intrinsic cisplatin resistance in human bladder cancer cell lines. Int J Oncol 16:1003-1007

24. Mathe G, Kidani Y, Segiguchi M, Eriguchi M, Fredj G, Peytavin G, Misset JL, Brienza S, de Vassals F, Chenu E, Bourut C (1991) Oxalato-platinum or 1-OHP, a third generation platinum complex: an experimental and clinical appraisal and preliminary comparison with cis-platinum and carboplatinum. Biomed Pharmacother 43:237-250

25. Rabik CA, Dolan ME (2007) Molecular mechanisms of resistance and toxicity associated with platinating agents. Cancer Treat Rev 33:9-23

26. Rajasekaran SA, Beyenbach KW, Rajasekaran AK (2008) Interactions of tight junctions with membrane channels and transporters. Biochim Biophys Acta 1778:757-769

27. Rajasekaran SA, Gopal J, Willis D, Espineda C, Twiss JL, Rajasekaran AK (2004) Na,K-ATPase beta1-subunit increases the translation efficiency of the alpha1-subunit in MSV-MDCK cells. Mol Biol Cell 15:3224-3232

28. Rajasekaran SA, Palmer LG, Quan K, Harper JF, Ball WJ Jr, Bander NH, Peralta SA, Rajasekaran AK (2001) Na,K-ATPase beta-subunit is required for epithelial polarization, suppression of invasion, and cell motility. Mol Biol Cell 12:279-295

29. Safaei R (2006) Role of copper transporters in the uptake and efflux of platinum containing drugs. Cancer Lett 234:34-39

30. Sherman-Baust CA, Weeraratna AT, Rangel LB, Pizer ES, Cho KR, Schwartz DR, Shock T, Morin PJ (2003) Remodeling of the extracellular matrix through overexpression of collagen VI contributes to cisplatin resistance in ovarian cancer cells. Cancer Cell 3:377-386

31. Shoshani L, Contreras RG, Roldan ML, Moreno J, Lazaro A, Balda MS, Matter K, Cereijido M (2005) The polarized expression of $\mathrm{Na}+\mathrm{K}+$-ATPase in epithelia depends on the association between beta-subunits located in neighboring cells. Mol Biol Cell 16:1071-1081

32. Tse J, Kalluri R (2007) Mechanisms of metastasis: epithelial to mesenchymal transition and contribution of tumor microenvironment. J Cell Biochem 101:816-829

33. Vagin O, Tokhtaeva E, Sachs G (2006) The role of the beta 1 subunit of the Na,K-ATPase and its glycosylation in cell-cell adhesion. J Biol Chem 281:39573-39587

34. Varma RR, Hector S, Clark K, Greco WR, Hawthorn L, Pendyala L (2005) Gene expression profiling of a clonal isolate of oxaliplatin resistant ovarian carcinoma cell line A2780/C10. Oncol Rep 14:925-932

35. Wiseman LR, Adkins JC, Plosker GL, Goa K (1999) Oxaliplatin. A review of its use in the management of metastatic colorectal cancer. Drugs Aging 14:459-475

36. Yang AD, Fan F, Camp ER, Van BG, Liu W, Somcio R, Gray MJ, Cheng H, Hoff PM, Ellis LM (2006) Chronic oxaliplatin resistance induces epithelial-to-mesenchymal transition in colorectal cancer cell lines. Clin Cancer Res 12:4147-4153

37. Zhang S, Lovejoy KS, Shima JE, Lagpacan LL, Shu Y, Lapuk A, Chen Y, Komori T, Gray JW, Chen X, Lippard SJ, Giacomini KM (2006) Organic cation transporters are determinants of oxaliplatin cytotoxicity. Cancer Res 66:8847-8857 